\title{
Antibactrial activity of Saponins extract from Lepudium aucheri boiss
}

\author{
https://doi.org/10.32792/utq/utj/vol10/1/9
}

\author{
Mohammed Q. Sultan, Sajid H. Gusar, Husam M. Kredy \\ College of sciences, Uviversity of Thi-Qar
}

\begin{abstract}
Saponins extract from Lepudium aucheri boiss was isolated and evaluated for antibacterial activity against gram negative and gram positive bacteria such as E.coli, Pseudomonas aeruginosa, Staphylococcus aureus, Streptococcus pneumoniae and Enterococcus faecalis. The inhibitory effect in vitro was defined to appear inhibition zone around the well. The study revealed that $75 \%(\mathrm{w} / \mathrm{v})$ concentration was most activity against these pathogenic bacteria.
\end{abstract}

Keywords: Extraction, L.aucheri boiss, Antibacterial activity

\section{Introduction}

Applications of medicinal plants are known to be used as food preservative due to its antimicrobial activity and antioxidant (1). Natural products have been a major source of new drugs(2). Researches on natural products have significantly progressed over the last decades, mainly on plants corroborating their importance to the discovery of new biological and medicinal agents $(3,4$, 5). Medicinal plants are a source for a wide variety of natural products, such as saponins and phenolic acids which are very interesting for their antioxidant properties (6). Lepudium aucheri boiss height ranges between around me $(2-15 \mathrm{~cm})$, with white petals spread in different of Iraq, especially in the desert areas in the addition to the area of the alluvial plain. This is due to the type genus lepidium L. Which comprises several types in Iraq including L.aucheri Boiss . It is one kind of family Cruciferae. Image (1) explained the L. aucheri Boiss (7). The taking conservation and use of medicinal plants. Saponins are steroid and triterpenoid glycosides common in a large number of plants and plants product that play an important role in human and animal nutrition. Several biological effect have been ascribed to saponins $(8,9)$ and they are also believed to form the main constituents of many plant drugs and folk medicines and are considered responsible for numerous pharmacology properties (10). Saponins consist of a sugar moiety usually containing glucose, galactose, glucuronic acid, xylose, rhamnose or methylpentose, glycosidically linked to a hydrophobic aglycone (sapogenin) which may be triterpenoid or 
Web Site: https://jutq.utq.edu.iq/index.php/main Email:journal@jutq.utq.edu.iq

steroid in nature $(11,12)$. Many saponins have detergent properties. They lower the surface tension of aqueous solution and therefore give stable foams when in contact with water. The aim of the present study was to evaluate antibacterial activity of saponin extract from L.aucheri Boiss against bacterial pathogens.

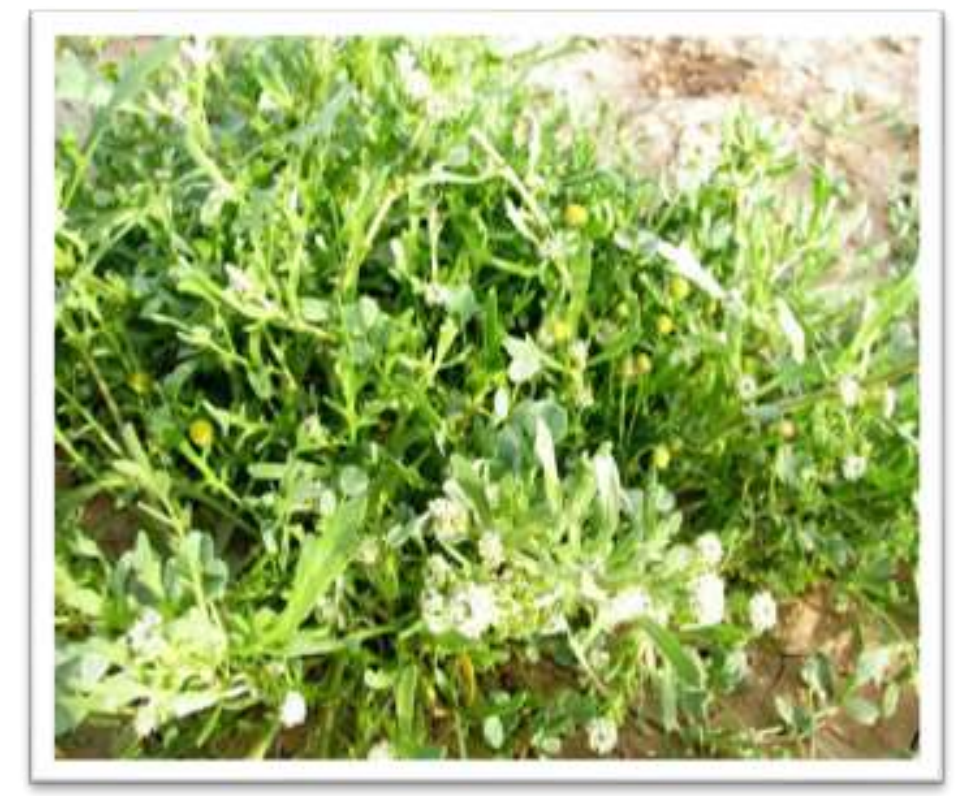

Image (1): Lepidium aucheri Boiss

\section{Material and method}

\section{Plants Collection:}

Lepidium aucheri boiss was collected in March 2013 from north - west of Nasiriyah city at Iraq, then it was authenticated and specimen of plant was classified in biological department-college of science at university oh Thi - Qar in Iraq by Asst. prof. Hyder Radhi . The plant were cleaned, washed by distilled water, dried at room temperature for weeks and dried under the shade , ground as powder and kept in dark glass containers for further use.

\section{Extraction of crude saponin from Lepidium aucheri boiss}

Air-dried powdered leaves of lepidium aucheri boiss (100 g) was extracted with $70 \%$ ethanol $(\mathrm{EtOH})(24 \mathrm{~h} \times 1000 \mathrm{~mL})$ at room temperature the $\mathrm{EtOH}$ solution was concentrate to a small volume $(300 \mathrm{ml})$ by low pressure evaporation at $45{ }^{\circ} \mathrm{C}$ and extracted in succession with chloroform $(24 \mathrm{~h} \times 100$ $\mathrm{ml} \times \mathrm{x}$ ) and $\mathrm{n}$-Butanol $(24 \mathrm{~h} \times 100 \mathrm{ml} \times 3)$. The $\mathrm{n}$-Butanol layer was concentrated to dryness given the saponins extract $(10 \mathrm{~g})(13,14)$. 
Web Site: https://jutq.utq.edu.iq/index.php/main Email:journal@jutq.utq.edu.iq

\section{Test of saponins compounds}

(1) Aqueous solution of saponin extract has prepared in test tube and was shaken after that product soapsuds was remaining and stable.

(2) $5 \mathrm{ml}$ from aqueous solution of saponin extract in test tube and added $5 \mathrm{ml}$ from $5 \%$ silver nitrate solution after that put in waterbath at $100{ }^{\circ} \mathrm{C}$ for 5 minutes when test tube cooled produced silver mirror on inner surface of the test tube (15).

\section{Antibacterial assay}

\section{Culture Media:}

Muller Hinton Agar was supplied from Himedia company (india), it was used as a culture medium and was prepared depending on information determining by manufacturing company .

\section{Pathogenic Bacterial Strains}

Staphylococcus aureus and Strep coccus and Enterococcus faecalis (positive to Gram stain), Escherichia coli and Pseudomonas aeruginosa (negative to Gram stain) were used as pathogenic bacteria strains and they were identified in biology dept. college of Science in Thi- Qar University.

\section{Assessment of Antibacterial Activity of Saponins Extracts}

Bacteria suspension of each tested bacteria $(107 \mathrm{CFU} / \mathrm{mL})$ was spread onto the surface of Muller-Hinton agar plates. Eight $\mathrm{mm}$ cork borer was used to punch wells into the plates and $100 \mu \mathrm{L}$ of each extract dissolved in DMSO $(50 \%$ and $75 \% \mathrm{w} / \mathrm{v})$ as well as were applied to each well. The plates were incubated for $18 \mathrm{~h}$ at $37^{\circ} \mathrm{C}$. The inhibition zones diameter for each concentration was measured and the saponins coefficient was calculated (16).

\section{Results and Discussion}

The result of test saponins in crude extracts from lepidium aucheri boiss gave stable foams in water for long time (more than one hour) and the second test procedure silver mirror on inner surface of the test tube table (1). Saponins have shown activity against a broad range of microorganisms including bacteria, filamentous fungi and yeasts $(17,18)$. The result of antibacterial activity are presented in table (1) which summarize the inhibition zone around the well measured by diameter. The concentration was $75 \%$ (w/v) more effective inhibition zone of Gram positive like Staphaureus (22mm), Streptococcus $(20 \mathrm{~mm})$, also Gram negative bacteria like Pseudomonas (15mm) table (2) . This results are similar to (19) with (20). We can use this study for development new antibacterial for need when some bacteria pathogen 
Web Site: https://jutq.utq.edu.iq/index.php/main Email:journal@jutq.utq.edu.iq

resistant to available antibiotic agents. Lepidium aucheri boiss plant more distribution in south and middle of Iraq and used in folk medicine, can help for make when new antibacterial cheap cost. When can isolation compounds of saponin from crude after that found which compound has highly biological activity, this is extract broad spectrum activity on both gram negative and gram positive.

Table (1): Qualitative tests ofsaponin extract in lepidium aucheri boiss

\begin{tabular}{|c||c||c|}
\hline Active principle & Test & Saponins Extract \\
\hline \hline \multirow{2}{*}{ Saponins } & shaking & + \\
\cline { 2 - 3 } & Silver nitrate & + \\
\hline
\end{tabular}

Table (2): Diameters of inhibition zone ( $\mathrm{mm}$ ) for all extracts

\begin{tabular}{|c|c|c|c|c|}
\hline \multirow[b]{2}{*}{$\begin{array}{l}\text { Type of } \\
\text { Bactria }\end{array}$} & \multicolumn{4}{|c|}{ Zone of inhibition in $\mathrm{mm}$} \\
\hline & Gram stain & $\begin{array}{l}50 \% \text { of } \\
\text { Saponins } \\
\text { Extracts }\end{array}$ & $\begin{array}{l}75 \% \text { of } \\
\text { Saponins } \\
\text { Extracts }\end{array}$ & $\begin{array}{c}\text { Control } \\
\text { (Ciprofloxacin) }\end{array}$ \\
\hline E.coli & - & 7 & 13 & 17 \\
\hline Pseudomonas & - & 10 & 15 & 20 \\
\hline Staphaureus & + & 16 & 22 & 24 \\
\hline Strep coccus & + & 13 & 20 & 22 \\
\hline $\begin{array}{c}\text { Enterococcus } \\
\text { faecalis }\end{array}$ & + & 10 & 14 & 16 \\
\hline DMSO & & 0 & 0 & \\
\hline
\end{tabular}




\section{University of Thi-Qar Journal Vol.10 No.1 Mar 2015}

Web Site: https://jutq.utq.edu.iq/index.php/main Email:journal@jutq.utq.edu.iq
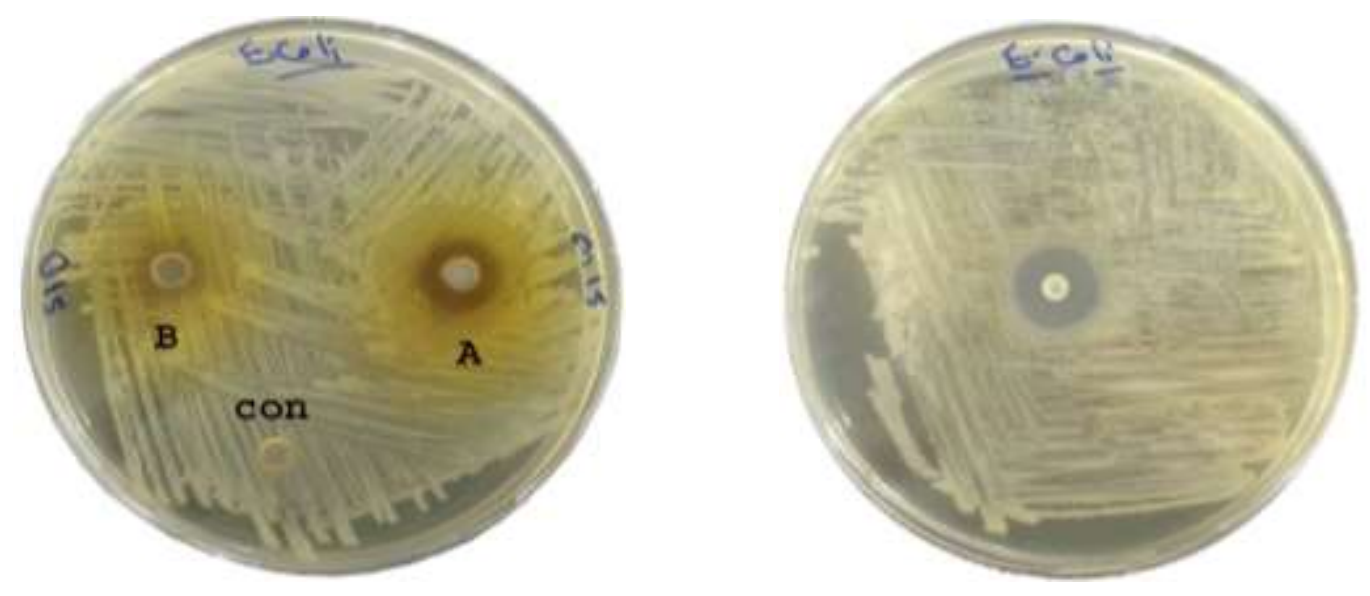

Figure (1): The activity of Saponins extracts against (E.Coli ) bacteria

1: A $75 \%$ Saponins extract

extract Con:

2: B $50 \%$ Saponins extract

(DMSO)
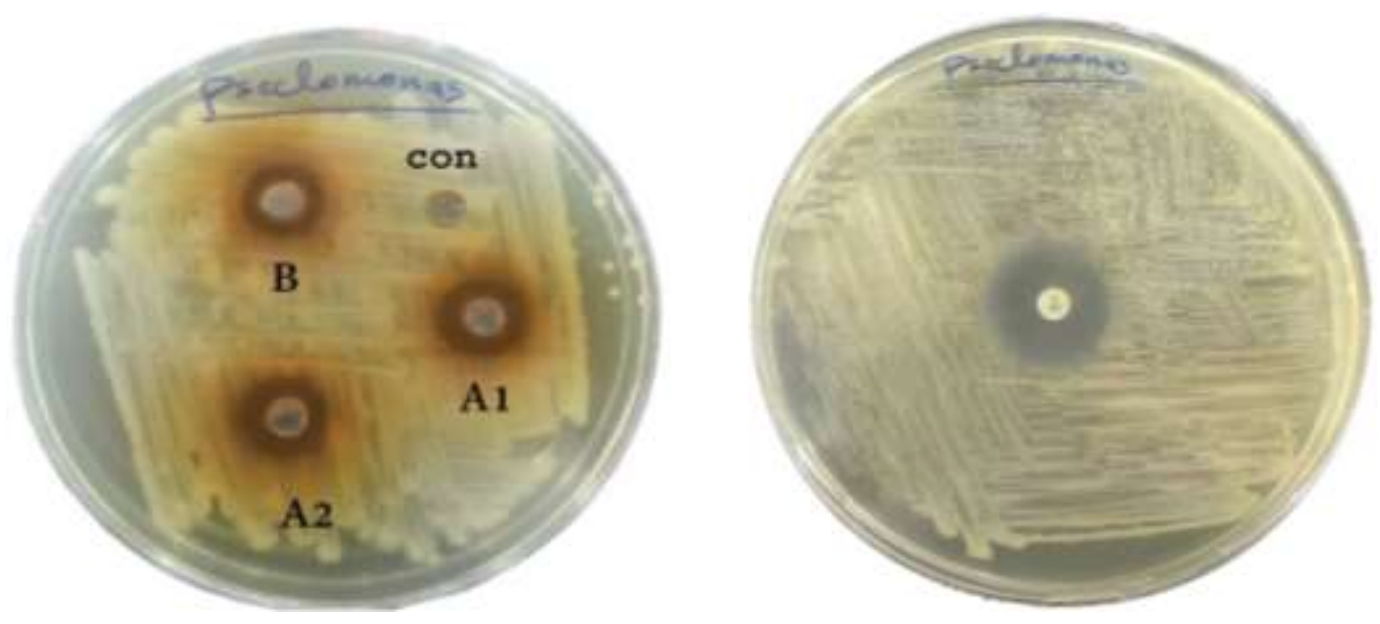

Figure (3):The activity of Saponins extracts against (Pseudo.) bacteria

Figure (4): The activity of Ciprodar against(Pseudo.)bacteriaPseudo: Pseudomonas aeruginosa . 


\section{University of Thi-Qar Journal Vol.10 No.1 Mar 2015}

Web Site: https://jutq.utq.edu.iq/index.php/main Email:journal@jutq.utq.edu.iq

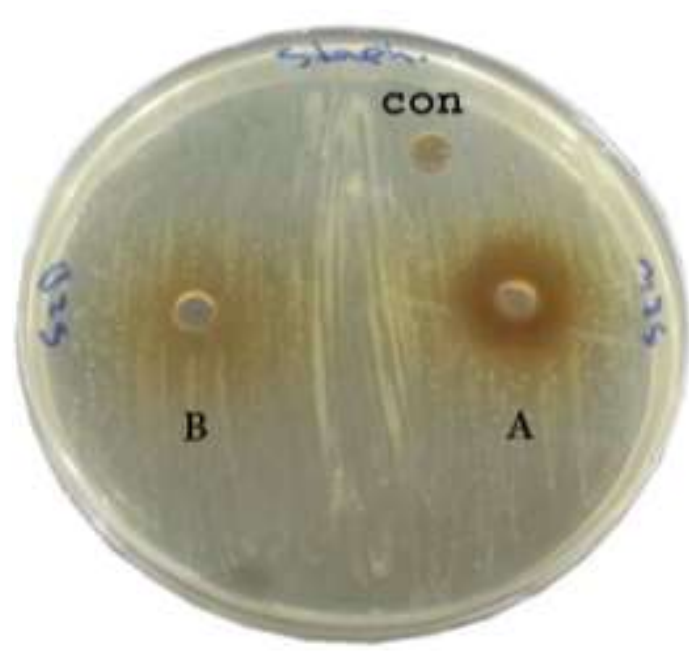

Figure (5): The activity of Saponins extracts against( Staph. )bacteria.

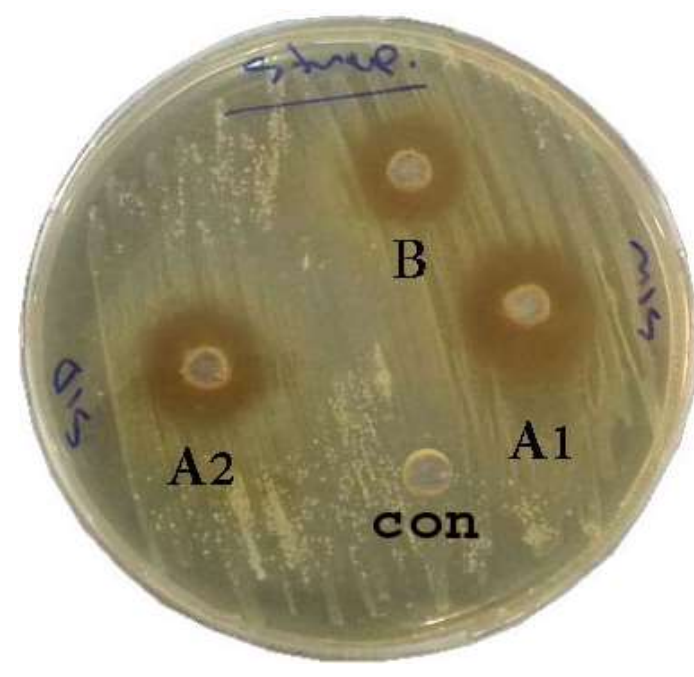

Figure (7):The activity of Saponins extracts against (Strep.) bacteria

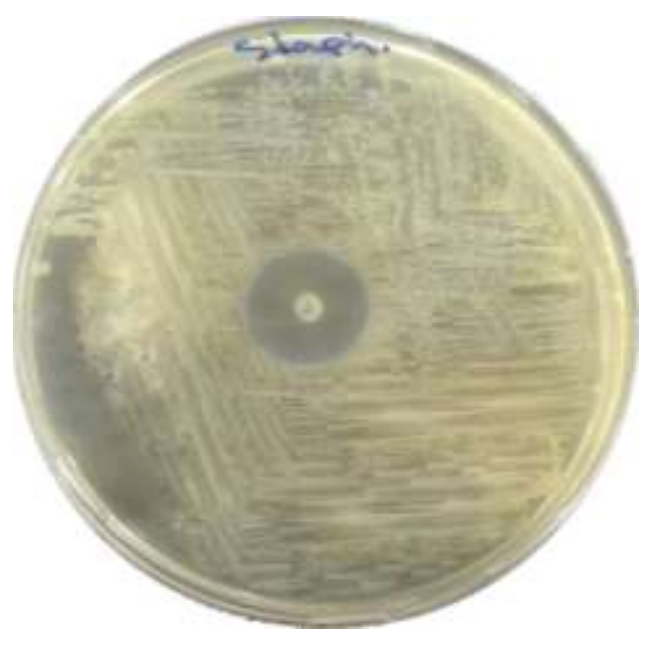

Figure (6): The activity of Ciprodar against (Staph.) bacteria Staph: Staphylococcus aureus.

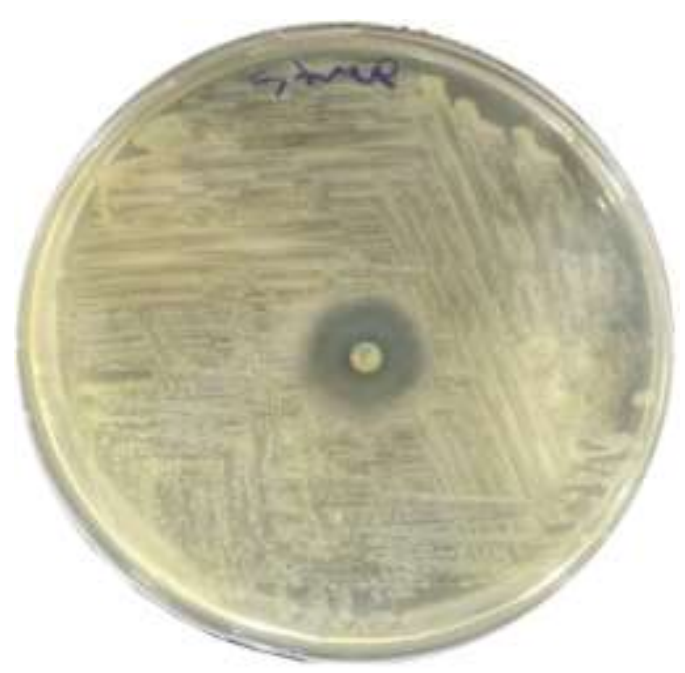

Figure (8): The activity of Ciprodar against (Strep.) bacteria

Strep. : Strepto coccus 


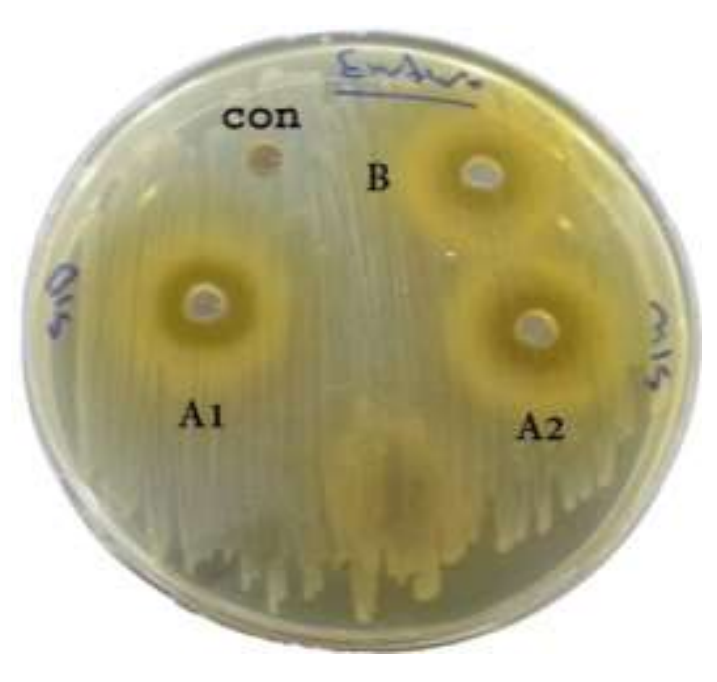

Figure (9): The activity of Saponins extracts against (Entero.) bacteria

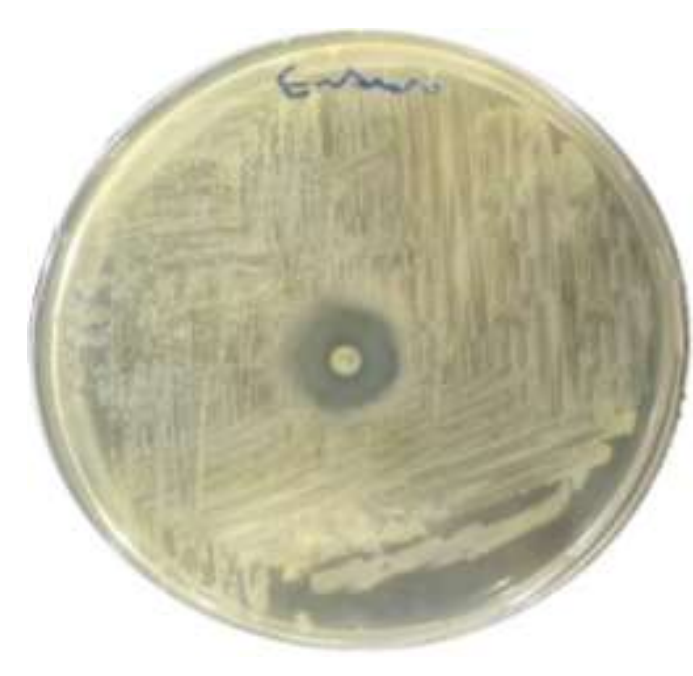

Figure (10): The activity of Ciprodar against (Entero.) bacteria Entero. : Entero coccus

\section{References:-}

1- Sunilson, J. A. J. R., Suraj, G., Rejitha, K., Anandarajagopal, A. V. A. G., Kumari and P. Promwichit. (2009). In vitro antimicrobial evaluation ofZingiber officinale, Curcuma longa and Alpinia galangal extracts as natural food preservatives. Am. J. Food Technol. 4: 192-200.

2- Vuorela, P., Leinonen, M., Saikku, P., Tammela, P., Wennberg, T. and Vuorela, H. (2004). Natural products in the process of finding new drug candidates.. Current Med. Chem. 11: 1375-1389.

3- Calixto, J. B. (2000). Efficacy, safety, quality control, marketing and regulatory guidelines for herbal medicines (phytotherapeutic agents). Braz. J. Med. Biol. Res. 33(2): 179-189.

4- Rates, S. M. K. (2001). Plants as source of drugs. Toxicon. 39: 603-613.

5- Newman, D. J., Cragg, G. M. and Snader, K. M. (2003). Natural products as sources of new drugs over the period 1981-2002. J. Nat. Prod. 66: 1022-1037. 


\section{University of Thi-Qar Journal Vol.10 No.1 Mar 2015}

Web Site: https://jutq.utq.edu.iq/index.php/main Email:journal@jutq.utq.edu.iq

6- Farhan, H., Rammal, H., Hijazi, A. and Badran B. (2012). Preliminary phytochemical screening and extraction of polyphenol from stems and leaves of a Lebanese plant Malva Parviflora. Int J Curr Pharm Res. 4(1): 5559.

7- Townsend, C. C. and Guest, E. (1980). Flora of Iraq. Minis. Agricu. Iraq. 4: 2. 886 .

8- Sparg, S. G., Light, M. E. and Van Staden, J. (2004). Biological activities and distribution of plant saponins. Journal of Ethnopharmacology 94(2-3) : 219-243.

9- Lacaille-Dubois, M. A. (2005). Bioactive saponins with cancer related and immunomodulatory activity: recent developments. Studies in Natural Products Chemistry 32(12): 209-246.

10- Liu, J. and Henkel. T. (2002). Traditional Chinese medicine (TCM): are polyphenols and saponins the key ingredients triggering biological activities. Current Medicinal Chemistry 9: 1483-1485.

11- Oleszek, W. and Bialy, Z. (2006). Chromatographic determination of plant saponins an update (2002-2005). Journal of Chromatography A 1112(1-2): 7891.

12- Bruneton, J. (2009). Pharmacognosie-phytochimie, plantes medicinales, 4eme edition, revue et augmente, Tec\&Doc-Edition Medicinales Internationals Paris. 1288 p.

13- Ivan kostova. Dragomir, D., Gudrun, H.R., Vladimir, D., Antoaneta, I. (2002). Two new sulfuted furostanol saponins from Tribulus terrestris. Zeitsschrift Naturforsch 57c. 33-38.

14- Flavio, H.R., Carla, K., Jan, S., Dominique, G., Grace, G., Eloir, P.S. (2001). Steroidal and triterpenoidal glucosides from Passiflora alata.J.Braz.Chem.Soc.vol.12(1): 32-36.

15- Shihata, I.M. (1951). A pharmacological study of anagllis arrensis, M.D. vet. Thesis. Cairo University.

16- Jeremiah, E. Angeh, Xueshi Huang, Gerry, E. Awan, Ute Mollman, Isabel Sattler and Jacobus N. Eloff. (2007). Novel antibacterial triterpenoid from Combretum Padoides . 113-120.

17- Lacaille-Dubois, M. A. and Wagner, H. (1996). A review of the biological and pharmacological activities of saponins. Phytomedicine. 4: 363-386.

18- Lacaille-Dubois, M. A. and Wagner, H. (1999). Bioactive saponins from plant: anupdate, in atta-ur-Raman(ed.), Studies in natural products chemistry of organic natural products Springer, Wien, New York, 74, 1-196.

19- Husam M. Kredy. (2010). Antibacterial activity of saponins extract from sider (Ziziphus spina-christi). Vol.6: 3-4.

20- Deboshree Biswas and Roymon, M. G. (2012). Validation of antibacterial activity of saponin against diarreagenic E.coli isolated from leave and bark of Acacia arabica. Journal of Phytology. 4(3) : 21-23. 
Web Site: https://jutq.utq.edu.iq/index.php/main Email:journal@jutq.utq.edu.iq

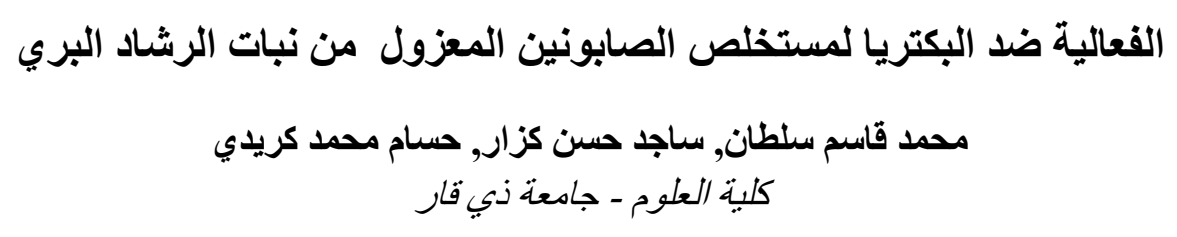

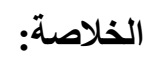

المركبات الصابونينية المعزولة من نبات الرشاد البري تمتلك تأثير مضاد للبكتريا السالبة لصبغة

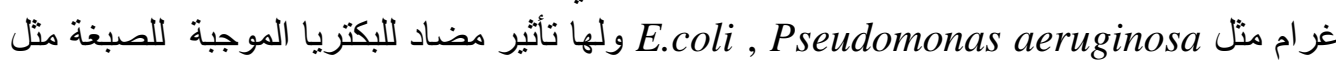
Staphylococcus aureus, Streptococcus pneumoniae Enterococcus, ظهر مختبريا يعرف بظهور منطقة التنبيط حول الحفرة وقد أظهرت الدراسة أن تركيز 75/v) \%

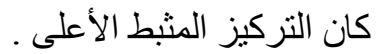

الكلمات المفتاحية: الاستخلاص, نبات الرشاد البري, الفعالية ضد البكتريا 